\title{
Microbial Cycling of $\mathrm{C}$ and $\mathrm{N}$ in Northern Hardwood Forests Receiving Chronic Atmospheric $\mathrm{NO}_{3}{ }^{-}$Deposition
}

\author{
Donald R. Zak, ${ }^{1,2 *}$ William E. Holmes, ${ }^{1}$ Matthew J. Tomlinson, ${ }^{1}$ \\ Kurt S. Pregitzer, ${ }^{3}$ and Andrew J. Burton ${ }^{3}$
}

\begin{abstract}
${ }^{1}$ School of Natural Resources \& Environment, University of Michigan, Ann Arbor, Michigan 48109-1114, USA; ${ }^{2}$ Department of Ecology and Evolutionary Biology, University of Michigan, Ann Arbor, Michigan 48109-1048, USA; ${ }^{3}$ School of Forest Resources $\&$ Environmental Science, Michigan Technological University, Houghton, Michigan 49937, USA
\end{abstract}

\begin{abstract}
Sugar maple (Acer saccharum Marsh.)-dominated northern hardwood forests in the upper Lakes States region appear to be particularly sensitive to chronic atmospheric $\mathrm{NO}_{3}{ }^{-}$deposition. Experimental $\mathrm{NO}_{3}{ }^{-}$deposition $\left(3 \mathrm{~g} \mathrm{NO}_{3}^{-} \mathrm{N} \mathrm{m}^{-2} \mathrm{y}^{-1}\right)$ has significantly reduced soil respiration and increased the export of DOC/DON and $\mathrm{NO}_{3}{ }^{-}$across the region. Here, we evaluate the possibility that diminished microbial activity in mineral soil was responsible for these ecosystem-level responses to $\mathrm{NO}_{3}{ }^{-}$deposition. To test this alternative, we measured microbial biomass, respiration, and $\mathrm{N}$ transformations in the mineral soil of four northern hardwood stands that have received 9 years of experimental $\mathrm{NO}_{3}{ }^{-}$deposition. Microbial biomass, microbial respiration, and daily rates of gross and net $\mathrm{N}$ transformations were not changed by $\mathrm{NO}_{3}{ }^{-}$ deposition. We also observed no effect of $\mathrm{NO}_{3}{ }^{-}$ deposition on annual rates of net $\mathrm{N}$ mineralization. However, $\mathrm{NO}_{3}{ }^{-}$deposition significantly increased $(27 \%)$ annual net nitrification, a response that
\end{abstract}

\section{INTRODUCTION}

On a global basis, human activity has altered the cycling of nitrogen $(\mathrm{N})$ in many terrestrial ecosys-

Received 25 June 2004; accepted 5 January 2005; published online 15 March 2006.

*Corresponding author; e-mail: drzak@umich.edu resulted from rapid microbial $\mathrm{NO}_{3}{ }^{-}$assimilation, the subsequent turnover of $\mathrm{NH}_{4}{ }^{+}$, and increased substrate availability for this process. Nonetheless, greater rates of net nitrification were insufficient to produce the 10-fold observed increase in $\mathrm{NO}_{3}{ }^{-}$ export, suggesting that much of the exported $\mathrm{NO}_{3}{ }^{-}$ resulted directly from the $\mathrm{NO}_{3}{ }^{-}$deposition treatment. Results suggest that declines in soil respiration and increases in DOC/DON export cannot be attributed to $\mathrm{NO}_{3}{ }^{-}$-induced physiological changes in mineral soil microbial activity. Given the lack of response we have observed in mineral soil, our results point to the potential importance of microbial communities in forest floor, including both saprotrophs and mycorrhizae, in mediating ecosystem-level responses to chronic $\mathrm{NO}_{3}{ }^{-}$deposition in Lake States northern hardwood forests.

Key words: microbial respiration; $\mathrm{N}$ mineralization; nitrification; atmospheric $\mathrm{NO}_{3}{ }^{-}$deposition; soil C and N cycling; northern hardwood forests. 
to form $\mathrm{HNO}_{3}$. Although forest productivity in these regions is often limited by soil $\mathrm{N}$ availability, chronic atmospheric $\mathrm{NO}_{3}{ }^{-}$deposition has the potential to surpass plant demand and initiate a cascade of events that culminate in $\mathrm{N}$ saturation (Aber and others $1989,1998)$. Forest ecosystems particularly prone to $\mathrm{N}$ saturation are those with rapid rates of soil $\mathrm{N}$ cycling that receive substantial atmospheric deposition (Emmett and others 1998). In the upper Great Lakes region, northern hardwood forests dominated by sugar maple (Acer saccharum Marsh.) are particularly susceptible to $\mathrm{N}$ saturation, because they have high rates of net $\mathrm{N}$ mineralization $\left(8-12 \mathrm{~g} \mathrm{~N} \mathrm{~m}^{-2} \mathrm{y}^{-1}\right.$; Zak and Pregitzer 1990) and moderate rates of atmospheric deposition (0.7-1.2 $\mathrm{g} \mathrm{N} \mathrm{m}^{-2} \mathrm{y}^{-1}$; MacDonald and others 1993). Recent evidence suggests that experimental $\mathrm{NO}_{3}{ }^{-}$deposition at levels already occurring in some portions of eastern North America (3 $\mathrm{g} \mathrm{NO}_{3}{ }^{-}-\mathrm{N} \mathrm{m}^{-2} \mathrm{y}^{-1}$; Fenn and others 1998) were sufficient to surpass the capacity of plants and soil microorganisms to retain $\mathrm{N}$, leading to high rates of $\mathrm{NO}_{3}{ }^{-}$export from this ecosystem (Pregitzer and others 2003; Zak and others 2004).

Atmospheric $\mathrm{NO}_{3}{ }^{-}$deposition also has the potential to influence the retention and loss of $\mathrm{C}$ in forest ecosystems by altering rates of soil respiration (Bowden and others 2000; Burton and others 2004). Respiration of plant roots and soil microorganisms control the flux of $\mathrm{CO}_{2}$ from soil, and there are reasons to expect that chronic $\mathrm{NO}_{3}{ }^{-}$deposition could alter root and microbial respiration. Fine root allocation and specific respiration rate are responsive to soil $\mathrm{N}$ availability, wherein fine root biomass often decreases (Vogt and others 1990; Haynes and Gower 1995) and specific respiration rate increases with greater soil $\mathrm{N}$ availability (Ryan and others 1996; Burton and others 1996, 2002). Increased soil $\mathrm{N}$ availability from chronic $\mathrm{NO}_{3}{ }^{-}$deposition could theoretically reduce the contribution of roots to soil respiration, if a decline in root biomass exceeds an increase in specific respiration. Moreover, soil respiration also could be reduced through a decline in mycorrhizae, thus decreasing mycorrhizal biomass and consequently respiration (Wallander 1995; Wallenda and Kottke 1998; Treseder and Allen 2000).

Depending on the biochemical composition of the decomposing material, atmospheric $\mathrm{NO}_{3}{ }^{-}$ deposition could have a variable effect on litter degradation, leading to increases or decreases in heterotrophic microbial respiration (Fog 1988); such a response should alter soil $\mathrm{N}$ cycling in a parallel manner. For example, high levels of $\mathrm{N}$ in soil solution, regardless of the form, can suppress the decomposition of plant detritus that is high in lignin and low in $\mathrm{N}$ (Fog 1988). In highly lignified litter, high $\mathrm{N}$ availability inhibits the synthesis of phenol oxidase and peroxidase by lignolytic, white rot Basidiomycota and xylariaceous Ascomycota (Keyser and others 1978; Kirk and Farrell 1987), producing an overall decline in litter decomposition (Carreiro and others 2000). In contrast, $\mathrm{N}$ applied to relatively low-lignin, high-N litter can stimulate decomposition (Carreiro and others 2000), and hence microbial respiration. These types of litter contain relatively large amounts of cellulose, the metabolism of which requires additional $\mathrm{N}$ for microbial growth on that substrate. Although sugar maple leaves are low in lignin (Melillo and others 1982), the fine roots of this plant species are a different case. Sugar maple fine roots contain substantial quantities of lignin (25-36\%; Parsons and others 2003; J. Eikenberry, unpublished data), almost three times greater than those occurring in leaves (ca. 10\%; Melillo and others 1982). One could argue that $\mathrm{NO}_{3}{ }^{-}$deposition could slow the decomposition of high-lignin fine root litter, due to the suppression of lignolytic activity. Alternatively, $\mathrm{NO}_{3}{ }^{-}$deposition might enhance the degradation of sugar maple leaf litter by supplying additional $\mathrm{N}$ for microbial growth on cellulose. Nitrate deposition could thereby increase or decrease litter degradation, microbial respiration, and the subsequent mineralization of $\mathrm{N}$, depending on the magnitude of sugar maple leaf (low lignin) versus root (high lignin) litter production.

We have been studying sugar maple-dominated northern hardwood stands in which experimental $\mathrm{NO}_{3}{ }^{-}$deposition (3 $\mathrm{g} \mathrm{N} \mathrm{m}^{-2} \mathrm{y}^{-1}$ since 1994) has reduced the activity of lignolytic and cellulolytic enzymes in litter and soil (Saiya-Cork and others 2002; DeForest and others 2004a, b, 2005), decreased soil respiration (Burton and others 2004), and increased the leaching export of DOC, DON and $\mathrm{NO}_{3}{ }^{-}$(Pregitzer and others 2003). However, we have found no significant effect of experimental $\mathrm{NO}_{3}{ }^{-}$deposition on fine root biomass, longevity, or specific respiration, suggesting that plant roots are not primarily responsible for observed declines in soil respiration (Burton and others 2004). In combination, these observations suggest that chronic $\mathrm{NO}_{3}{ }^{-}$deposition has significantly altered soil $\mathrm{C}$ and $\mathrm{N}$ cycling in these northern hardwood forests, but we do not yet understand how $\mathrm{NO}_{3}{ }^{-}$deposition has altered microbial respiration and the subsequent mineralization of N. Our objectives here were to evaluate: (a) the possibility that reductions in soil respiration under experimental $\mathrm{NO}_{3}{ }^{-}$deposition result from lower rates of microbial respiration in soil, and (b) 
the potential for observed declines in lignolytic and cellulolytic activity to slow rates of soil $\mathrm{N}$ cycling. After 9 years of experimental $\mathrm{NO}_{3}{ }^{-}$deposition, we measured microbial respiration, microbial biomass, and microbial $\mathrm{N}$ transformations in mineral soil to determine whether chronic $\mathrm{NO}_{3}{ }^{-}$deposition has reduced microbial respiration or slowed rates of soil $\mathrm{N}$ cycling.

\section{MeTHODS}

\section{Experimental Design}

We investigated the influence of experimental atmospheric $\mathrm{NO}_{3}{ }^{-}$deposition on soil microbial processes in four northern hardwood stands located across lower and upper Michigan, USA. These sites are floristically and edaphically similar, but they differ in climate along a north-south latitudinal gradient (Table 1; MacDonald and others 1993). They also span the entire geographic distribution of northern hardwood forests in the Upper Lake States region. Located in each site are six $30 \mathrm{~m} \times 30 \mathrm{~m}$ plots, to which we assigned atmospheric $\mathrm{N}$ deposition treatments. Three plots in each stand receive ambient $\mathrm{N}$ deposition (Table 1), and they form our control treatment. The remaining three plots receive ambient $\mathrm{N}$ deposition plus $3 \mathrm{~g} \mathrm{NO}_{3}{ }^{-}-\mathrm{N} \mathrm{m}^{-2} \mathrm{y}^{-1}$ ( $\mathrm{N}$-amended treatment), a rate equivalent to atmospheric $\mathrm{N}$ deposition in eastern North America and portions of Europe (Bredemeier and others 1998; Fenn and others 1998). The additional $\mathrm{NO}_{3}{ }^{-}$ is delivered over the growing season in six equal applications $\left(0.5 \mathrm{~g} \mathrm{~N} \mathrm{~m}^{-2}\right.$ month $\left.^{-1}\right)$ of solid $\mathrm{NaNO}_{3}$. Our experiment was initiated in 1994, and the data we report here were gathered after 9 years of continuous treatment.

\section{Microbial C, Respiration, Net N Mineralization and Net Nitrification}

During the 2002-2003 field season, we collected mineral soil cores from three random locations in each control and $\mathrm{N}$-amended plot. Samples were collected monthly during the growing season, but not during winter snow cover (October 2002-April 2003). At each random location, the Oi and Oe horizons were removed, and we extracted a $10-\mathrm{cm}$ deep core (5.27 cm dia.) of mineral soil consisting of $\mathrm{A}$ and $\mathrm{E}$ horizon. These cores were placed on ice and transported to the laboratory for measurement of microbial biomass, microbial respiration and $\mathrm{NH}_{4}{ }^{+}$ and $\mathrm{NO}_{3}{ }^{-}$pools. At the same time, a second core was removed at each random location. We placed these cores in polyethylene bags ( $1 \mathrm{~mL}$ thickness) and returned them to their original position in the soil profile; Oi and Oa horizon material was then replaced. These cores remained in the field until the subsequent sampling date, on which they were removed from the soil profile, placed on ice, and transported to the laboratory for analysis of $\mathrm{NH}_{4}{ }^{+}$ and $\mathrm{NO}_{3}{ }^{-}$. Freshly collected and field-incubated cores were homogenized by hand within each polyethylene bag, and all visible roots were removed prior to chemical or biological analysis.

Microbial $\mathrm{C}$ was determined using the fumigation-incubation procedure (Voroney and Paul 1984). A 20-g subsample from each freshly collected soil core (that is, not incubated in the field) was fumigated for $18 \mathrm{~h}$ with $\mathrm{CH}_{3} \mathrm{CH}_{2} \mathrm{OH}$-free $\mathrm{CHCl}_{4}$ in a vacuum desiccator. A second 20 -g subsample from the same freshly collected core was simultaneously incubated in a moist desiccator $\left(\right.$ no $\left.\mathrm{CHCl}_{3}\right)$ to act as a control. After repeated vacuuming and aeration (eight volumes) to eliminate residual $\mathrm{CHCl}_{3}$, each fumigated sample was inoculated with $0.5 \mathrm{~g}$ of soil from the paired non-fumigated sample. Fumigated and non-fumigated soils were incubated for 10 days at $25^{\circ} \mathrm{C}$ in $1 \mathrm{~L}$ Mason jars equipped with septa. After the 10-day incubation, headspace gas samples $(0.4$ $\mathrm{mL}$ ) were analyzed for $\mathrm{CO}_{2}$ using a Trace 200 Series gas chromatograph (Thermo Electron Corp., Austin, TX) equipped with a Porapak Q column (50/80 mesh; Waters Chromotography, Millipore Corp., Milford, MA) and a thermal conductivity detector. Microbial C $\left(\mu \mathrm{g} \mathrm{C} \mathrm{g}^{-1}\right)$ was calculated by dividing the flush of $\mathrm{CO}_{2}-\mathrm{C}$ from fumigated samples by 0.41 (Voroney and Paul 1984). The production of $\mathrm{CO}_{2}$ from the non-fumigated, control samples was used to estimate microbial respiration ( $\mu \mathrm{g} \mathrm{CO}_{2}-\mathrm{C} \mathrm{g}^{-1} \mathrm{~d}^{-1}$ ).

A 20-g subsample from each freshly collected soil core and from each field-incubated core was extracted with $20 \mathrm{~mL}$ of $2 \mathrm{~mol} / \mathrm{L} \mathrm{KCl}$. The soil-solution mixture was passed through a Whatman 42 filter, and the extract was analyzed for $\mathrm{NH}_{4}{ }^{+}$and $\mathrm{NO}_{3}{ }^{-}$ using an OI Analytical Flow Solution 3000 continuous flow analyzer (OI Analytical, College Station, Texas, USA). We compared extractable $\mathrm{NH}_{4}{ }^{+}$and $\mathrm{NO}_{3}{ }^{-}$in freshly collected cores from control and $\mathrm{N}$-amended plots to assess the influence of experimental $\mathrm{N}$ deposition on these soil pools. Monthly net $\mathrm{N}$ mineralization ( $\mathrm{ng} \mathrm{N} \mathrm{g}^{-1} \mathrm{~d}^{-1}$ ) was calculated as accumulation of $\mathrm{NH}_{4}{ }^{+}-\mathrm{N}+\mathrm{NO}_{3}{ }^{-}-\mathrm{N}$ in field-incubated cores over amounts in field fresh cores collected at the start of the field incubation. The difference in $\mathrm{NO}_{3}{ }^{-}-\mathrm{N}$ between field-incubated and freshly collected cores was used to estimate monthly net nitrification. Calculations of net $\mathrm{N}$ mineralization and net nitrification were based on differences between individual field-incubated and field fresh 
Table 1. Climatic, Floristic and Edaphic Characteristics of Four Northern Hardwood Sites receiving Experimental Atmospheric $\mathrm{NO}_{3}{ }^{-}$Deposition

\begin{tabular}{|c|c|c|c|c|}
\hline & \multicolumn{4}{|c|}{ Site } \\
\hline & A & B & $\mathrm{C}$ & $\mathrm{D}$ \\
\hline \multicolumn{5}{|l|}{ Location } \\
\hline Latitude, $\mathrm{N}$ & $46^{\circ} 52^{\prime}$ & $45^{\circ} 33^{\prime}$ & $44^{\circ} 23^{\prime}$ & $43^{\circ} 40^{\prime}$ \\
\hline Longitude, W & $88^{\circ} 53^{\prime}$ & $84^{\circ} 52^{\prime}$ & $85^{\circ} 50^{\prime}$ & $86^{\circ} 09^{\prime}$ \\
\hline \multicolumn{5}{|l|}{ Climate } \\
\hline Mean Annual Temperature $\left({ }^{\circ} \mathrm{C}\right)$ & 4.8 & 6.1 & 6.9 & 7.6 \\
\hline Mean Annual Precipitation (mm) & 821 & 828 & 856 & 793 \\
\hline Wet + Dry $\mathrm{NO}_{3}{ }^{-}-\mathrm{N}$ Deposition $\left(\mathrm{g} \mathrm{m}^{-2} \mathrm{y}^{-1}\right)$ & 0.38 & 0.58 & 0.78 & 0.76 \\
\hline Wet + Dry Total $\mathrm{N}$ Deposition $\left(\mathrm{g} \mathrm{m}^{-2} \mathrm{y}^{-1}\right)$ & 0.68 & 0.91 & 1.17 & 1.18 \\
\hline \multicolumn{5}{|l|}{ Vegetation } \\
\hline Stand Age ${ }^{a}$ (years) & 97 & 91 & 92 & 95 \\
\hline Overstory Biomass (Mg/ha) & 261 & 261 & 274 & 234 \\
\hline Acer saccharum Biomass ( $\mathrm{Mg} / \mathrm{ha})$ & 237 & 224 & 216 & 166 \\
\hline \multicolumn{5}{|l|}{ Soil $(0-10 \mathrm{~cm})$} \\
\hline Sand $(\%)$ & 85 & 89 & 89 & 87 \\
\hline pH (1:1 soil: $\left.\mathrm{H}_{2} \mathrm{O}\right)$ & 4.83 & 5.03 & 4.47 & 4.66 \\
\hline Organic C (mg C/g) & 19.0 & 19.4 & 15.4 & 18.4 \\
\hline $\begin{array}{l}\text { Sites are located in lower and upper Michigan, USA, and they ha } \\
\text { soil development, but they differ in temperature and growing se } \\
{ }^{a} \text { Stand age in } 2004 \text {. }\end{array}$ & perimer & on since 1 & similar in & osition, and \\
\hline
\end{tabular}

cores collected at the three random locations in each plot. Both net $\mathrm{N}$ mineralization and net nitrification were expressed as daily rates $\left(\mathrm{ng} \mathrm{N} \mathrm{g}^{-1} \mathrm{~d}^{-1}\right)$ over the 1 -month incubation. We estimated annual rates of net $\mathrm{N}$ mineralization and net nitrification by summing rates over the year and extrapolating to an areal basis using soil bulk density.

\section{Gross N Transformations and the Flow of ${ }^{15} \mathrm{NH}_{4}{ }^{+}$and ${ }^{15} \mathrm{NO}_{3}{ }^{-}$}

On our June sample date, we determined gross rates of $\mathrm{N}$ mineralization and nitrification (Davidson and others 1992; Hart and others 1994) and traced inorganic ${ }^{15} \mathrm{~N}$ from soil solution into microbial biomass and soil organic matter (sensu Holmes and others 2003). For this analysis, we composited an equal mass from the three freshly collected cores removed from each plot, samples that we individually analyzed as described above. Five 12-g subsamples of the composited soil from each plot were weighed into glass vials; this was the same soil we used to determine microbial $\mathrm{C}$, rates of microbial respiration, and soil $\mathrm{NH}_{4}{ }^{+}$and $\mathrm{NO}_{3}{ }^{-}$pools. Two soil samples contained in vials were enriched with $1 \mathrm{~mL}$ of ${ }^{15} \mathrm{NH}_{4} \mathrm{Cl}$ solution, two were enriched with the same volume of $\mathrm{K}^{15} \mathrm{NO}_{3}$ solution, and the remaining sample received $1 \mathrm{~mL}$ of deionized water. The
${ }^{15} \mathrm{~N}$ solutions were prepared using a mixture of ${ }^{15} \mathrm{~N}$ labeled $(99.5 \%)$ and unlabelled $\mathrm{N}$, which produced similar target concentrations of $\mathrm{N}\left(2-5 \mu \mathrm{g} \mathrm{N} \mathrm{g}^{-1}\right.$ soil) and ${ }^{15} \mathrm{~N}\left(2-4\right.$ atom \% excess $\left.{ }^{15} \mathrm{~N}\right)$ in both ${ }^{15} \mathrm{NH}_{4}{ }^{+}$ and ${ }^{15} \mathrm{NO}_{3}{ }^{-}$labeled soil. Solutions containing ${ }^{15} \mathrm{~N}$ were applied evenly over the soil surface. The $1 \mathrm{~mL}$ volume was adequate to disperse the label evenly throughout each 12-g sample, as indicated by uniform wetting of the entire soil volume; it brought the soil to field capacity. Within $1 \mathrm{~h}$ after isotope addition, one ${ }^{15} \mathrm{NH}_{4}{ }^{+}$-enriched sample and one ${ }^{15} \mathrm{NO}_{3}{ }^{-}$-enriched sample was extracted with $2 \mathrm{~mol} /$ $\mathrm{L} \mathrm{KCl}$; samples amended with deionized water also were extracted at this time. The remaining ${ }^{15} \mathrm{NH}_{4}{ }^{+}$enriched and ${ }^{15} \mathrm{NO}_{3}{ }^{-}$-enriched samples were incubated at $20^{\circ} \mathrm{C}$ for 2 days, after which, we extracted inorganic $\mathrm{N}$ with $2 \mathrm{~mol} / \mathrm{L} \mathrm{KCl}$.

We devised a sequential extraction procedure to isolate tracer ${ }^{15} \mathrm{~N}$ within each soil $\mathrm{N}$ pool (Holmes and others 2003). In the first step, inorganic $\mathrm{N}$ $\left(\mathrm{NH}_{4}{ }^{+}\right.$and $\left.\mathrm{NO}_{3}{ }^{-}\right)$and DON was separated from microbial $\mathrm{N}$ and soil organic $\mathrm{N}$. To accomplish this task, $20 \mathrm{~mL}$ of $2 \mathrm{~mol} / \mathrm{L} \mathrm{KCl}$ was added to each sample in its original vial. The vials were capped, placed on a shaker $20 \mathrm{~min}$ and centrifuged for 15 min at $800 \mathrm{rpm}$. The supernatant was decanted into a $60 \mathrm{~mL}$ plastic syringe equipped with a $0.45 \mu \mathrm{m}$ filter attachment. The extraction was repeated with 
a second $20-\mathrm{mL}$ aliquot of $2 \mathrm{~mol} / \mathrm{L} \mathrm{KCl}$. Particulate organic matter and suspended cells were removed from the $\mathrm{KCl}$ solution by forcing them though the $0.45 \mu \mathrm{m}$ filter; the resulting filtrate contained inorganic $\mathrm{N}$ and DON. The filter from each syringe was placed back into the vial containing the corresponding soil. Filtrates were stored in $120-\mathrm{mL}$ specimen cups at $4^{\circ} \mathrm{C}$ prior to isotopic analysis.

A second extraction step was performed to separate microbial $\mathrm{N}$ and soil organic $\mathrm{N}$. Vials containing soils and filters (containing microbial cells) were fumigated with $\mathrm{CH}_{3} \mathrm{Cl}$ for 5 days in a vacuum desiccator. Residual $\mathrm{CH}_{3} \mathrm{Cl}$ was removed by repeated vacuuming (eight times) and $20 \mathrm{~mL}$ of $0.25 \mathrm{~mol} / \mathrm{L}$ $\mathrm{K}_{2} \mathrm{SO}_{4}$ was added to each vial. Vials were capped, placed on a shaker for $30 \mathrm{~min}$, and centrifuged for $15 \mathrm{~min}$ at $800 \mathrm{rpm}$. The supernatant was decanted into a $120-\mathrm{mL}$ specimen cup. This extraction was repeated with an additional $20-\mathrm{mL}$ aliquot of $\mathrm{K}_{2} \mathrm{SO}_{4}$, and the extracts were frozen until they were digested to determine microbial $\mathrm{N}$. The soil samples remaining in the vials were dried to a constant weight at $60^{\circ} \mathrm{C}$ in a forced-air oven. The dried soils were transferred to grinding jars, pulverized with stainless steel pins $(0.5 \mathrm{~cm} \mathrm{D} \times 13.8 \mathrm{~cm} \mathrm{~L})$ in a roller mill (Model 755RMV, U.S. Stoneware, East Palestine, $\mathrm{OH}$ ), and stored for analysis of organic $\mathrm{N}$.

Ammonium- $\mathrm{N}$ and $\mathrm{NO}_{3}{ }^{-}-\mathrm{N}$ concentrations in filtered $\mathrm{KCl}$ extracts were measured as described above. Ammonium- $\mathrm{N}$ and $\mathrm{NO}_{3}{ }^{-}-\mathrm{N}$ were sequentially diffused from the $\mathrm{KCl}$ extracts onto acid traps in preparation for ${ }^{15} \mathrm{~N}$ analysis (Brooks and others 1989). Following diffusion of inorganic N, we used alkaline persulfate digestion to convert DON into $\mathrm{NO}_{3}$, which was subsequently diffused onto an acid trap as described above. The acid traps containing $\mathrm{NH}_{4}{ }^{+}, \mathrm{NO}_{3}{ }^{-}$, and DON were analyzed for atom \% ${ }^{15} \mathrm{~N}$ on a Finnigan Delta Plus isotope ratio mass spectrometer with a Conflo II interface (Thermo Finnigan, San Jose, CA).

Microbial $\mathrm{N}$ within the $\mathrm{K}_{2} \mathrm{SO}_{4}$ extracts also was determined by alkaline persulfate digestion (Cabrera and Beare 1993). Blanks and glycine standards were digested simultaneously with samples. A 3-mL aliquot of each digest was used to determine its $\mathrm{NO}_{3}{ }^{-}{ }^{-} \mathrm{N}$ concentration, as described above. Nitrate- $\mathrm{N}$ in the remaining digest was captured on acid traps during a 5-day diffusion with MgO and Devarda's alloy. The acid traps were analyzed for atom $\%{ }^{15} \mathrm{~N}$ by isotope ratio mass spectrometry.

Soil organic $\mathrm{N}$ concentration was measured using a CE Instruments NC2500 elemental analyzer (CE Elantech, Lakewood, $\mathrm{NJ}$ ). Atom $\%{ }^{15} \mathrm{~N}$ in soil organic $\mathrm{N}$ was then determined by isotope ratio mass spectrometry. We used the resulting $\mathrm{N}$ concentra- tion and atom $\%{ }^{15} \mathrm{~N}$ data to calculate recovery of ${ }^{15} \mathrm{~N}$ label within inorganic $\mathrm{N}$, microbial $\mathrm{N}$ and soil organic $\mathrm{N}$ pools following the 2-day incubation. For each pool, we calculated atom $\%{ }^{15} \mathrm{~N}$ excess (APE) using atom $\%{ }^{15} \mathrm{~N}$ of the same pool in the wateramended control as background. We calculated rates of gross $\mathrm{N}$ mineralization and nitrification, and rates of gross $\mathrm{N}$ immobilization, using the isotope pool dilution equations of Hart and others (1994).

\section{Statistical Analyses}

We used a repeated-measures two-way analysis of variance (ANOVA) to determine the influence of study site and $\mathrm{NO}_{3}{ }^{-}$deposition on microbial respiration, net $\mathrm{N}$ mineralization, net nitrification and extractable $\mathrm{NH}_{4}{ }^{+}$and $\mathrm{NO}_{3}{ }^{-}$pools. In this design, forest sites $(n=4)$ and $\mathrm{NO}_{3}{ }^{-}$deposition $(n=2)$ were main effects; our analysis also included an interaction between the two main effects. All data used in these analyses were plot means, which were obtained by averaging values from the three random locations within each plot. To compare main effect and interaction means, we used a protected Fisher's LSD procedure. To investigate the influence of $\mathrm{NO}_{3}{ }^{-}$deposition on annual $\mathrm{N}$ rates of net $\mathrm{N}$ mineralization and nitrification, as well as gross $\mathrm{N}$ transformations, we used a two-way ANOVA in which sites and $\mathrm{NO}_{3}{ }^{-}$deposition treatment were main effects; this analysis also included an interaction between main effects. Site, $\mathrm{NO}_{3}{ }^{-}$ deposition and interaction means were compared using a protected Fisher's LSD procedure.

\section{Results}

\section{Microbial C, Respiration, Net N Mineralization and Net Nitrification}

Although site was a significant main effect in our analysis of microbial $\mathrm{C}, \mathrm{NO}_{3}{ }^{-}$deposition was not, and there was no interaction between these main effects (Table 2). Sites A $(341 \pm 27.2 \mu \mathrm{C} / \mathrm{g}$; mean \pm se) and B $(300 \pm 2.1 \mu \mathrm{C} / \mathrm{g})$ in the northern portion of the gradient had significantly greater amounts of microbial $\mathrm{C}$ than the two more southern sites (Site C $=194 \pm 11.9 \mu \mathrm{C} / \mathrm{g}$; Site $\mathrm{D}=224 \pm 13.4 \mu \mathrm{C} / \mathrm{g})$. Averaged across sites and sampling dates, microbial $\mathrm{C}$ in control plots was $276 \pm 14.6 \mu \mathrm{C} / \mathrm{g}$, a value that was not significantly different from microbial $\mathrm{C}$ in $\mathrm{NO}_{3}{ }^{-}$amended plots $(252 \pm 14.6 \mu \mathrm{C} / \mathrm{g})$. We found a significant interaction among time, site and $\mathrm{NO}_{3}{ }^{-}$deposition (Table 2), but there was no consistent pattern in 
Table 2. Two-way Repeated-measures Analysis of Variance for Microbial Biomass and Activity in Four Northern Hardwood Sites receiving Experimental Atmospheric $\mathrm{NO}_{3}{ }^{-}$Deposition

\begin{tabular}{|c|c|c|c|c|c|c|c|c|c|c|}
\hline \multirow[b]{2}{*}{ ANOVA } & \multicolumn{3}{|c|}{ Microbial C } & \multicolumn{3}{|c|}{ Microbial Respiration } & \multicolumn{2}{|c|}{$\begin{array}{c}\text { Net } \mathrm{N} \\
\text { Mineralization }\end{array}$} & \multicolumn{2}{|c|}{$\begin{array}{c}\text { Net } \\
\text { Nitrification }\end{array}$} \\
\hline & $\begin{array}{l}\text { Degrees } \\
\text { of Freedom }\end{array}$ & $\begin{array}{l}\text { Mean } \\
\text { Square }\end{array}$ & $F$ & $\begin{array}{l}\text { Degrees } \\
\text { of Freedom }\end{array}$ & $\begin{array}{l}\text { Mean } \\
\text { Square }\end{array}$ & $F$ & $\begin{array}{l}\text { Mean } \\
\text { Square }\end{array}$ & $F$ & $\begin{array}{l}\text { Mean } \\
\text { Square }\end{array}$ & $F$ \\
\hline \multicolumn{11}{|l|}{ Between Subjects } \\
\hline Site & 3 & 192,980 & $7.5^{* *}$ & 3 & 1930.5 & $28.5^{* *}$ & 0.14 & 1.35 & 0.38 & $5.44^{* *}$ \\
\hline $\mathrm{NO}_{3}{ }^{-}$Deposition & 1 & 21,532 & 0.8 & 1 & 0.9 & 0.0 & 0.34 & $3.34^{*}$ & 0.12 & 1.72 \\
\hline Site $\times \mathrm{NO}_{3}{ }^{-}$Deposition & 3 & 35,833 & 1.4 & 2 & 195.4 & $2.9^{*}$ & 0.23 & $2.26^{*}$ & 0.08 & 1.23 \\
\hline Error & 16 & 25,846 & & 16 & 67.7 & & 0.10 & & 0.07 & \\
\hline \multicolumn{11}{|l|}{ Within Subjects } \\
\hline Month & 7 & 18,003 & 1.6 & 6 & 157.8 & $6.1^{* *}$ & 3.06 & $27.96^{* *}$ & $0.64 \quad 1$ & $10.70^{* * *}$ \\
\hline Month $\times$ Site & 21 & 14,094 & 1.2 & 18 & 81.5 & $3.2^{* *}$ & 0.21 & $1.95^{*}$ & 0.06 & 1.01 \\
\hline Month $\times \mathrm{NO}_{3}{ }^{-}$Dep. & 7 & 14,078 & 1.2 & 6 & 6.6 & 0.2 & 0.22 & $2.06^{*}$ & 0.07 & 1.26 \\
\hline Month $\times$ Site $\times \mathrm{NO}_{3}{ }^{-}$Dep. & 21 & 38,918 & $3.5^{* *}$ & 18 & 21.1 & 0.8 & 0.17 & 0.07 & 0.06 & 1.00 \\
\hline Error & 112 & 11,318 & & 96 & 25.6 & & 0.11 & & 0.06 & \\
\hline
\end{tabular}

Significance is indicated by the following symbols: $* * * P \leq 0.001 ; * * P \leq 0.01, * P \leq 0.1$.

the response of microbial $\mathrm{C}$ to our $\mathrm{N}$ deposition treatments across time or sites. The interaction between time and $\mathrm{NO}_{3}{ }^{-}$deposition treatment was not significant (Figure 1A), and microbial C varied little across sampling dates in both treatments. We also found no interaction with time and site, nor was time a significant main effect in our analysis, indicating that microbial $\mathrm{C}$ remained relatively consistent over our year-long study (Table 2).

Microbial respiration was significantly influenced by a site $\mathrm{x} \mathrm{NO}_{3}{ }^{-}$deposition interaction, indicating there was no consistent treatment response across sites (Table 2). For example, $\mathrm{NO}_{3}{ }^{-}$deposition produced decreases (Site A), increases (Sites B and D), and no change (Site $C$ ) in microbial respiration relative to the control treatment (data not shown). Although site had a significant main effect on microbial respiration, $\mathrm{NO}_{3}{ }^{-}$deposition treatment had no effect on this process (Table 2). In general, site differences in microbial respiration paralleled those in microbial biomass, with the northern sites ( $\mathrm{A}$ and $\mathrm{B}$; $13-16 \mu \mathrm{CO}_{2}-\mathrm{C} \mathrm{g}^{-1} \mathrm{~d}^{-1}$ ) having greater rates than the southern sites ( $\mathrm{C}$ and $\mathrm{D} ; 8-9 \mu \mathrm{CO}_{2}-\mathrm{C}$ $\left.\mathrm{g}^{-1} \mathrm{~d}^{-1}\right)$. Mean rates of microbial respiration for control $\left(11.8 \pm 0.70 \mu \mathrm{CO}_{2}-\mathrm{C} \mathrm{g}^{-1} \mathrm{~d}^{-1}\right)$ and $\mathrm{NO}_{3}{ }^{-}$ amended $\left(11.7 \pm 0.65 \mu \mathrm{CO}_{2}-\mathrm{C} \mathrm{g}^{-1} \mathrm{~d}^{-1}\right)$ treatments were virtually identical. This relationship was consistent across sampling dates and produced no significant time $\times$ treatment interaction (Figure $1 \mathrm{~B})$. Both time and a time $\times$ site interaction were significant; rates were generally lowest during mid-summer and greatest during spring, but there was no consistent ranking among stands over time.
Net $\mathrm{N}$ mineralization rates $\left(\mathrm{ng} \mathrm{N} \mathrm{g} \mathrm{g}^{-1} \mathrm{~d}^{-1}\right)$ were significantly influenced by a site $\times \mathrm{NO}_{3}{ }^{-}$deposition interaction (Table 2), again indicating that there was not a consistent response to $\mathrm{NO}_{3}{ }^{-}$ deposition across sites. Although $\mathrm{NO}_{3}{ }^{-}$deposition was a significant main effect, mean daily rates in the control treatment $\left(430 \pm 24.8 \mathrm{ng} \mathrm{N} \mathrm{g}^{-1} \mathrm{~d}^{-1}\right)$ were only slightly greater than those in the $\mathrm{NO}_{3}{ }^{-}$ amended treatment $\left(418 \pm 19.9 \mathrm{ng} \mathrm{N} \mathrm{g} \mathrm{d}^{-1}\right)$; this small difference is not ecologically important. Time had a significant effect on daily rates of net $\mathrm{N}$ mineralization, and time also interacted with site and $\mathrm{NO}_{3}{ }^{-}$deposition treatment to influence this process. The significant time $\times$ site interaction occurred because the rank order of sites changed during the growing season (data not shown). During the June-July sampling period, greater daily rates of net $\mathrm{N}$ mineralization in the control treatment, relative to the $\mathrm{NO}_{3}{ }^{-}$deposition treatment, resulted in a significant time $\times \mathrm{NO}_{3}{ }^{-}$ deposition treatment interaction (Table 2, Figure $2 \mathrm{~A}$ ). Time was a significant main effect (Table 2), due to high daily rates of net $\mathrm{N}$ mineralization during spring-summer, relative to the low rates in early spring or late autumn. Although annual rates of net $\mathrm{N}$ mineralization significantly differed among sites $(P=0.005 ; 8.0 \mathrm{~g} \mathrm{~N}$ $\mathrm{m}^{-2} \mathrm{y}^{-1}$ in Site B versus $10-11 \mathrm{~g} \mathrm{~N} \mathrm{~m}^{-2} \mathrm{y}^{-1}$ in Sites A, C, and D), chronic $\mathrm{NO}_{3}{ }^{-}$deposition had no effect on this process. Annual rates of net $\mathrm{N}$ mineralization averaged $9.9 \pm 0.37 \mathrm{~g} \mathrm{~N} \mathrm{~m}^{-2} \mathrm{y}^{-1}$ in the control and $9.7 \pm 0.51 \mathrm{~g} \mathrm{~N} \mathrm{~m}^{-2} \mathrm{y}^{-1}$ in the $\mathrm{NO}_{3}{ }^{-}$amended treatments. 

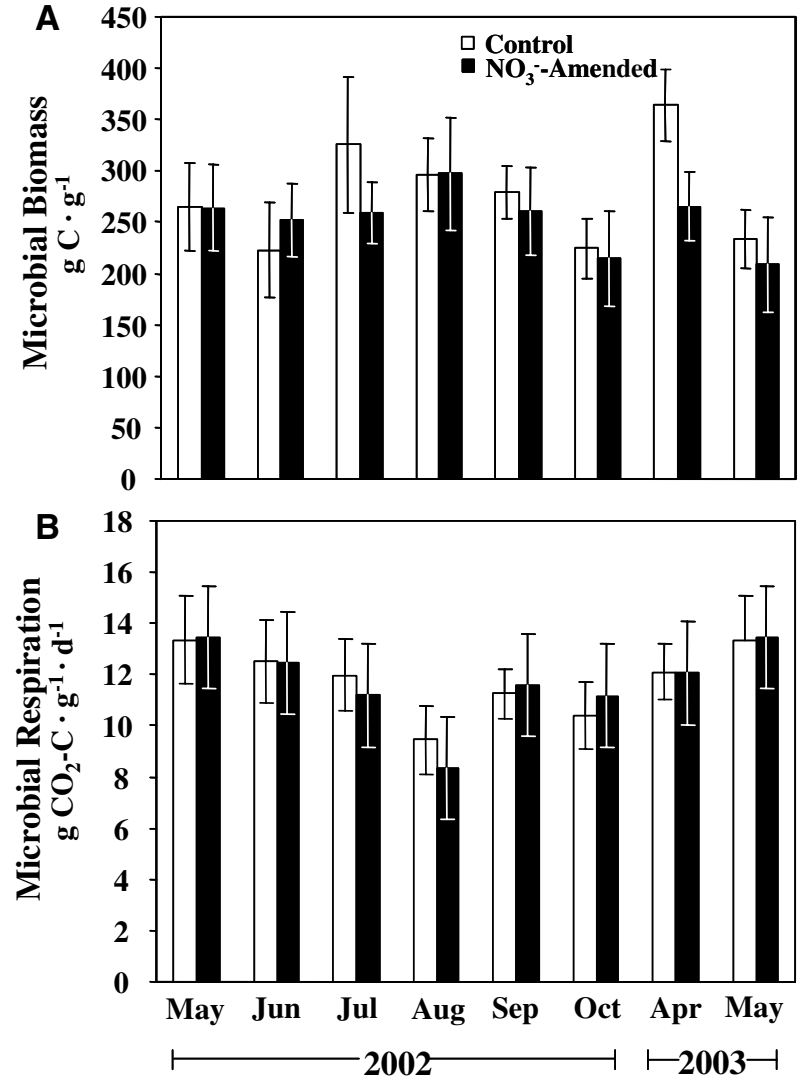

Figure 1. Temporal patterns of microbial biomass (A) and microbial respiration $(\mathbf{B})$ in northern hardwood sites receiving experimental atmospheric $\mathrm{NO}_{3}{ }^{-}$deposition. Values are treatment means of four sites located in lower and upper Michigan, USA. On each sampling date, we found no significant difference between control and $\mathrm{N}$-amended plots. The half-length of each bar is one standard error.

Net nitrification (ng $\mathrm{N} \mathrm{g}^{-1} \mathrm{~d}^{-1}$ ) differed significantly among sites, but $\mathrm{NO}_{3}{ }^{-}$deposition did not alter this process (Table 2 ). Mean daily rates in the control treatment were $186 \pm 20.7 \mathrm{ng} \mathrm{N} \mathrm{g}^{-1} \mathrm{~d}^{-1}$ and they were $233 \pm 20.3 \mathrm{ng} \mathrm{N} \mathrm{g}^{-1} \mathrm{~d}^{-1}$ in the $\mathrm{NO}_{3}{ }^{-}$ amended treatment; these rates were not significantly different. Time had a significant influence on daily net nitrification rates, but we observed no significant interaction between time and treatment (Figure 2B). In general, daily rates were greatest during mid-growing season and least in spring and autumn. Mean annual net nitrification differed significantly among sites $(P=0.001)$, directly paralleling pattern in annual net $\mathrm{N}$ mineralization. Nitrate deposition treatment also significantly $(P=0.019)$ altered annual net nitrification, with rates in the $\mathrm{NO}_{3}{ }^{-}$amended treatment $(5.6 \pm 0.31 \mathrm{~g}$ $\left.\mathrm{N} \mathrm{m}^{-2} \mathrm{y}^{-1}\right)$ exceeding those in the control treatment $\left(4.4 \pm 0.46 \mathrm{~g} \mathrm{~N} \mathrm{~m}^{-2} \mathrm{y}^{-1}\right)$.
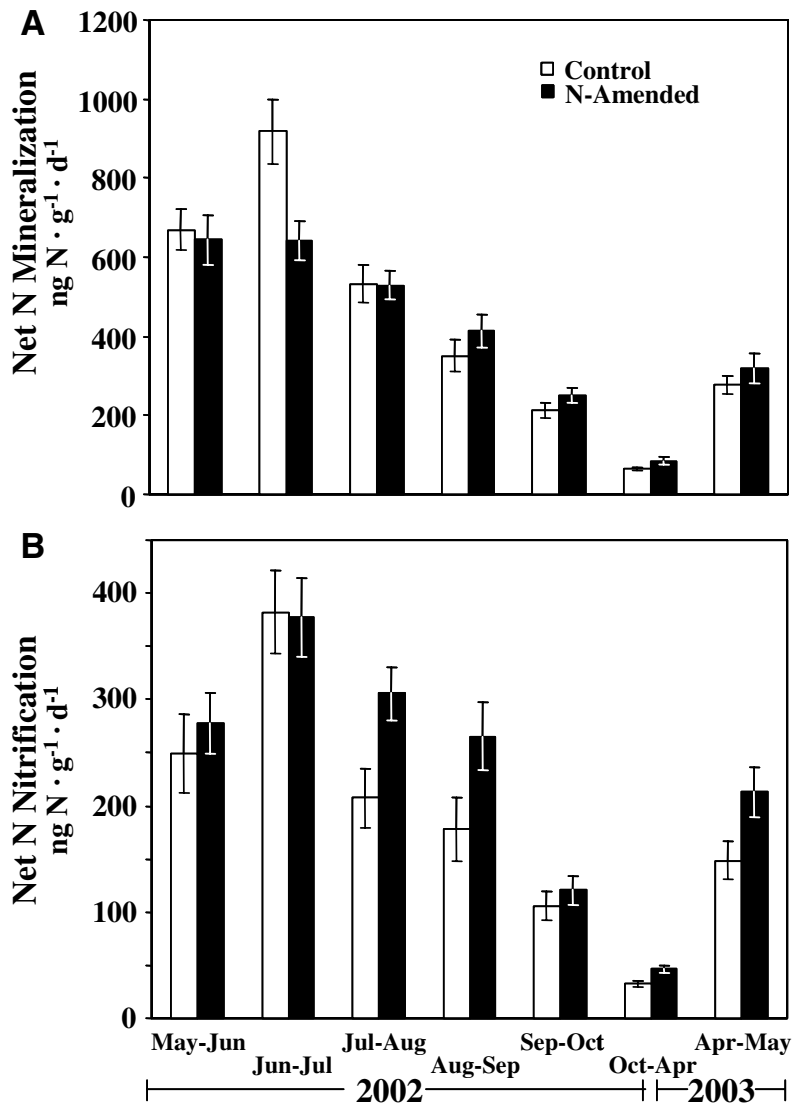

Figure 2. Net $\mathrm{N}$ mineralization $(\mathbf{A})$ and net nitrification (B) in northern hardwood sites receiving experimental atmospheric $\mathrm{NO}_{3}{ }^{-}$deposition. Values are treatment means of four sites located in lower and upper Michigan, USA. We observed no consistent treatment effect over time on net $\mathrm{N}$ mineralization, whereas net nitrification was generally higher under experimental atmospheric $\mathrm{NO}_{3}{ }^{-}$deposition. The half-length of each bar is one standard error.

We consistently observed significantly greater concentrations of extractable $\mathrm{NO}_{3}{ }^{-}$in the $\mathrm{NO}_{3}{ }^{-}$ amended treatment $\left(5.3 \pm 0.27 \mu \mathrm{g} \mathrm{NO}_{3}{ }^{-}-\mathrm{N} \mathrm{g} \mathrm{g}^{-1}\right)$ compared to the control $(P<0.001 ; 3.9 \pm 0.16 \mu \mathrm{g}$ $\mathrm{NO}_{3}{ }^{-}-\mathrm{N} \mathrm{g}^{-1}$ ), but $\mathrm{NO}_{3}{ }^{-}$deposition treatment had no effect on extractable $\mathrm{NH}_{4}^{+} \quad(P=0.341$; $4.1 \pm 0.22 \mu \mathrm{g} \mathrm{NH} \mathrm{NH}_{4}^{+}-\mathrm{N} \mathrm{g}^{-1}$ in control versus $4.4 \pm 0.38 \mu \mathrm{g} \mathrm{NH}_{4}{ }^{+}-\mathrm{N} \mathrm{g}^{-1}$ in $\mathrm{NO}_{3}{ }^{-}$amended treatment).

Gross $\mathrm{N}$ Transformations and the Flow of ${ }^{15} \mathrm{NH}_{4}{ }^{+}$and ${ }^{15} \mathrm{NO}_{3}{ }^{-}$

We used short-term ${ }^{15} \mathrm{~N}$ pool dilution to estimate gross rates of $\mathrm{N}$ transformations on our June 2002 sampling date, and we found no effect of our $\mathrm{NO}_{3}{ }^{-}$ deposition treatment on these processes. Although 
Table 3. The Influence of Experimental $\mathrm{NO}_{3}{ }^{-}$Deposition on Gross $\mathrm{N}$ Mineralization, Nitrification and the Microbial Immobilization of $\mathrm{NH}_{4}^{+}$and $\mathrm{NO}_{3}{ }^{-}$

\begin{tabular}{lcc}
\hline Process & Control $\left(\mu \mathrm{g} \mathrm{N} \mathrm{g}^{-1} \mathrm{~d}^{-1}\right)$ & $\mathrm{NO}_{3}^{-}$-Amended $\left(\mu \mathrm{g} \mathrm{g} \mathrm{g}^{-1} \mathrm{~d}^{-1}\right)$ \\
\hline Gross N Mineralization & $5.35 \mathrm{a}$ & $5.06 \mathrm{a}$ \\
& $(0.401)$ & $(0.604)$ \\
Gross Nitrification & $1.58 \mathrm{a}$ & $1.55 \mathrm{a}$ \\
& $(0.169)$ & $(0.192)$ \\
Gross $\mathrm{NH}_{4}{ }^{+}$Immobilization & $0.97 \mathrm{a}$ & $1.88 \mathrm{a}$ \\
& $(0.280)$ & $(0.489)$ \\
Gross $\mathrm{NO}_{3}{ }^{-}$Immobilization & $0.53 \mathrm{a}$ & $0.37 \mathrm{a}$ \\
& $(0.182)$ & $(0.132)$
\end{tabular}

Values are means averaged across four northern hardwood sites in lower and upper Michigan, USA. Means in a row with the same letter are not significantly different; standard errors are enclosed within parentheses.

sites differed significantly in rates of gross $\mathrm{N}$ mineralization $(P=0.006)$ and nitrification $(P=0.010)$, mean rates were equivalent in the control and $\mathrm{NO}_{3}{ }^{-}$ amended treatments (Table 3). Although shortterm rates of $\mathrm{NH}_{4}{ }^{+}$immobilization displayed a $90 \%$ increase in the $\mathrm{NO}_{3}{ }^{-}$amended treatment, this difference was not significant (Table 3). Microbial immobilization of $\mathrm{NO}_{3}{ }^{-}$also was not influenced by $\mathrm{NO}_{3}{ }^{-}$deposition treatment (Table 3). Microbial biomass $\mathrm{N}$ was similarly not influenced by our $\mathrm{NO}_{3}{ }^{-}$ deposition treatment $(P=0.849)$, but it did differ significantly among sites $(P<0.001$; data not shown). We traced labeled $\mathrm{NH}_{4}{ }^{+}$and $\mathrm{NO}_{3}{ }^{-}$in our isotope dilution study into microbial biomass, dissolved organic $\mathrm{N}$ and soil organic $\mathrm{N}$, but we found no significant influence of $\mathrm{NO}_{3}{ }^{-}$deposition on the movement of isotope among these soil pools (Table 4). Over the 2-day experiment, substantially more ${ }^{15} \mathrm{NO}_{3}{ }^{-}$(ca. $25 \%$ ) was recovered in soil organic $\mathrm{N}$ than ${ }^{15} \mathrm{NH}_{4}{ }^{+}$(ca. 2-5\%).

\section{Discussion}

Chronic atmospheric $\mathrm{NO}_{3}{ }^{-}$deposition has the potential to alter rates of $\mathrm{C}$ and $\mathrm{N}$ cycling in northern hardwood forests, but we found no effects on microbial biomass, microbial respiration, and $\mathrm{N}$ cycling following 9 years of experimental $\mathrm{NO}_{3}{ }^{-}$deposition. These results are somewhat surprising, given our previous observations of greater DOC/DON export, lower lignolytic and cellulolytic enzyme activity, and a reduction in soil respiration induced by chronic $\mathrm{NO}_{3}{ }^{-}$deposition (DeForest and others 2004a, b; Pregitzer and others 2003; Burton and others 2004). These responses all signal significant changes in the microbial transformation of plant litter constituents into soil organic matter. Although the results presented here appear to be disparate from previous observations, this study focused on microbial communities in mineral soil and it is clear that experimental $\mathrm{NO}_{3}{ }^{-}$deposition has not produced physiological changes that give rise to declines in soil respiration and soil $\mathrm{N}$ cycling or increases in the byproducts (that is, DOC/DON) of litter degradation. Thus, it appears that the aforementioned responses to $\mathrm{NO}_{3}{ }^{-}$deposition may be occurring in the forest floor, the initial entry point for anthropogenic $\mathrm{NO}_{3}{ }^{-}$into the soil system.

In the northern hardwood stands we have studied, experimental $\mathrm{NO}_{3}{ }^{-}$deposition has produced a $15 \%$ decline in soil $\mathrm{CO}_{2}$ flux after 8 years of application (Burton and others 2004). However, lower rates of in soil respiration cannot be attributed to a decline in root respiration, because neither root biomass nor specific respiration was influenced by experimental $\mathrm{NO}_{3}{ }^{-}$deposition (Burton and others 2004). This led us to speculate that declines in soil respiration arose from lower rates of microbial respiration in mineral soil, a response that is consistent with a decline in lignolytic and cellulolytic extracellular enzyme activity (DeForest and others 2004a, b, 2005). In the northeastern US, 13 years of experimental $\mathrm{N}$ deposition also reduced soil respiration $14-41 \%$ in an oak- and pine-dominated forests amended with $5-15 \mathrm{~g} \mathrm{~N} \mathrm{~m}^{-2} \mathrm{y}^{-1}$ (Bowden and others 2004). In the aforementioned experiment, microbial respiration in mineral soil declined by approximately $65 \%$ in both forests, indicating that lower rates of soil respiration resulted from a reduction in mineral soil microbial activity (Bowden and others 2004). In contrast, we have no evidence that $\mathrm{NO}_{3}{ }^{-}$deposition has altered microbial respiration in mineral soil, because mean rates were virtually identical between our ambient and $\mathrm{NO}_{3}{ }^{-}$deposition treatments ( 11.8 vs. $11.7 \mu \mathrm{CO}_{2}-\mathrm{C} \mathrm{g}^{-1} \mathrm{~d}^{-1}$, respectively). 
Table 4. The Effect of Experimental $\mathrm{NO}_{3}{ }^{-}$Deposition on the Recovery of ${ }^{15} \mathrm{NH}_{4}{ }^{+}$or ${ }^{15} \mathrm{NO}_{3}{ }^{-}$in Soil Pools

\begin{tabular}{|c|c|c|c|c|}
\hline \multirow[b]{2}{*}{ Soil N Pool } & \multicolumn{2}{|c|}{${ }^{15} \mathrm{NH}_{4}{ }^{+}$Labeled Soil (\%) } & \multicolumn{2}{|c|}{${ }^{15} \mathrm{NO}_{3}$ Labeled Soil (\%) } \\
\hline & Control & $\mathrm{NO}_{3}{ }^{-}$-Amended & Control & $\mathrm{NO}_{3}{ }^{-}$-Amended \\
\hline Extractable $\mathrm{NH}_{4}{ }^{+}$ & $\begin{array}{l}63.0 \mathrm{a} \\
(3.49)\end{array}$ & $\begin{array}{l}61.1 \mathrm{a} \\
(1.99)\end{array}$ & $\begin{array}{c}0.41 \mathrm{a} \\
(0.05)\end{array}$ & $\begin{array}{c}0.36 a \\
(0.03)\end{array}$ \\
\hline Extractable $\mathrm{NO}_{3}^{-}$ & $\begin{array}{c}4.5 \mathrm{a} \\
(1.50)\end{array}$ & $\begin{array}{c}5.5 \mathrm{a} \\
(1.15)\end{array}$ & $\begin{array}{l}60.6 \mathrm{a} \\
(0.55)\end{array}$ & $\begin{array}{l}62.1 \mathrm{a} \\
(1.46)\end{array}$ \\
\hline Microbial N & $\begin{array}{c}7.9 \mathrm{a} \\
(0.52)\end{array}$ & $\begin{array}{c}7.8 \mathrm{a} \\
(0.50)\end{array}$ & $\begin{array}{c}1.4 \mathrm{a} \\
(0.15)\end{array}$ & $\begin{array}{c}1.4 \mathrm{a} \\
(0.14)\end{array}$ \\
\hline Dissolved Organic N & $\begin{array}{c}0.4 \mathrm{a} \\
(0.08)\end{array}$ & $\begin{array}{c}0.5 a \\
(0.16)\end{array}$ & $\begin{array}{c}1.8 \mathrm{a} \\
(0.93)\end{array}$ & $\begin{array}{c}3.7 a \\
(1.34)\end{array}$ \\
\hline Soil Organic N & $\begin{array}{c}2.5 \mathrm{a} \\
(1.43)\end{array}$ & $\begin{array}{c}4.9 \mathrm{a} \\
(1.96)\end{array}$ & $\begin{array}{l}25.9 \mathrm{a} \\
(2.61)\end{array}$ & $\begin{array}{l}25.3 a \\
(2.95)\end{array}$ \\
\hline Total ${ }^{15} \mathrm{~N}$ Recovery & $\begin{array}{l}78.0 \mathrm{a} \\
(2.32)\end{array}$ & $\begin{array}{l}79.8 \mathrm{a} \\
(2.04)\end{array}$ & $\begin{array}{l}90.2 \mathrm{a} \\
(2.94)\end{array}$ & $\begin{array}{l}92.8 \mathrm{a} \\
(4.30)\end{array}$ \\
\hline
\end{tabular}

Values are mean ${ }^{15} \mathrm{~N}$ recoveries averaged across four northern hardwood sites in lower and upper Michigan, USA. For each labeled compound, means in a row with the same letter are not significantly different; standard errors are enclosed in parentheses.

If neither root respiration nor microbial respiration in mineral soil is responsible for a reduction in soil respiration in our study, then what process has $\mathrm{NO}_{3}{ }^{-}$deposition altered to produce this response?

Our previous field measurement of soil respiration included respiration occurring in both organic and mineral soil horizons, whereas our laboratory measurement of microbial respiration was conducted on root-free, surface mineral soil (A and $\mathrm{E}$ horizons). As a consequence, estimates of microbial respiration did not include the activity of heterotrophic microorganisms metabolizing leaf litter on the soil surface. In our previous work, $\mathrm{NO}_{3}{ }^{-}$ deposition decreased lignolytic activity in forest floor to a greater extent than in mineral soil. For example, phenol oxidase activity in forest floor exhibited a significant $35 \%$ reduction in response to $\mathrm{NO}_{3}{ }^{-}$deposition, but this response was not significant in mineral soil $(-5 \%$; DeForest and others 2004a). Peroxidase, another enzyme involved with lignin degradation, exhibited a similar response to our treatments. Although $\mathrm{NO}_{3}{ }^{-}$deposition has produced significant reductions in cellulolytic activity ( $\beta$-glucosidase, $-23 \%$ ) and microbial biomass (total phospholipid fatty acid, $-19 \%$; DeForest and others 2004a, b) in mineral soil, they appear to be insufficient to alter rates of microbial respiration. Given the greater declines in forest floor microbial activity, $\mathrm{NO}_{3}{ }^{-}$deposition may have reduced soil respiration by lowering heterotrophic activity in forest floor; it clearly has not diminished root and microbial respiration in mineral soil. Additionally,
$\mathrm{NO}_{3}{ }^{-}$deposition could lower allocation to mycorrhizal fungi, and hence the respiration of these organisms, a response that would lead to lower rates of soil respiration. Our data cannot directly address these potential mechanisms, and further study is required to determine if either contributed to the decline in soil respiration observed in our previous work.

If $\mathrm{NO}_{3}{ }^{-}$deposition has altered microbial activity in forest floor, then it will be important to better understand the interaction of $\mathrm{NO}_{3}{ }^{-}$deposition and tissue biochemistry on the microbial metabolism of leaf litter. We have argued that $\mathrm{NO}_{3}{ }^{-}$deposition could have a variable effect on litter decomposition that depends on its initial lignin and cellulose concentration. Several studies have documented that $\mathrm{N}$ added to leaf litter with a low lignin concentration, like that of sugar maple, can accelerate decomposition (Fog 1988; Carreiro and others 2000). It follows that accelerated rates of litter decomposition should result in higher rates of microbial respiration, but this was not borne out in our findings. It is plausible that greater rates of decomposition in the presence of additional $\mathrm{NO}_{3}{ }^{-}$ altered the microbial degradation of leaf litter to produce more DOC and less $\mathrm{CO}_{2}$, especially if rates of lignin depolymerization were substantially reduced as we have previously observed (DeForest and others 2004a, b). In wetlands, the limitation of phenol oxidase by low $\mathrm{pO}_{2}$ leads to the production of soluble phenolics, and $\mathrm{NO}_{3}{ }^{-}$deposition may be eliciting a similar response in forest floor. This 
chain of events is consistent with both a decline in lignolytic activity and an increase in DOC/DON export from the $\mathrm{NO}_{3}{ }^{-}$amended treatment (DeForest and others 2004a, b; Pregitzer and others 2003). Nevertheless, it will be necessary to directly measure microbial respiration and DOC/DON production from fresh leaf litter and forest floor to confirm whether such a mechanism is at work in our experiment.

We have no evidence that potential declines in cellulolytic and lignolytic activity produced by experimental $\mathrm{NO}_{3}{ }^{-}$deposition (DeForest and others 2004a) have slowed soil microbial N transformations, at least not in surface mineral soil. The results we report here indicate that $\mathrm{NO}_{3}{ }^{-}$deposition did not alter rates of net $\mathrm{N}$ mineralization, nor did it alter gross rates of $\mathrm{N}$ mineralization, microbial immobilization and nitrification. Our $\mathrm{NO}_{3}{ }^{-}$deposition treatment also had no effect on the movement of ${ }^{15} \mathrm{NH}_{4}{ }^{+}$or ${ }^{15} \mathrm{NO}_{3}{ }^{-}$into any soil pool. These results are very different from other experiments in which experimental $\mathrm{N}$ deposition has accelerated rates of microbial $\mathrm{N}$ transformations. In a compositionally similar forest in the northeastern U.S., 12 years of chronic atmospheric $\mathrm{N}$ deposition [ca. $3 \mathrm{~g}$ $\mathrm{N} \mathrm{m}^{-2} \mathrm{y}^{-1}$ as $\left(\mathrm{NH}_{4}\right)_{2} \mathrm{SO}_{4}$ ] increased net $\mathrm{N}$ mineralization by $20 \%$ in forest floor, and by a smaller margin in mineral soil (9\%; Jefts and others 2004). In this same study, increased rates of net $\mathrm{N}$ mineralization also occurred in spruce-fir receiving the same level of chronic $\mathrm{N}$ deposition, and similar observations have been made in coniferous forests in Europe (Gundersen and others 1998). Experimental $\mathrm{NO}_{3}{ }^{-}$deposition $\left(4 \mathrm{~g} \mathrm{NO}_{3}{ }^{-}-\mathrm{N} \mathrm{m}^{-2} \mathrm{y}^{-1}\right)$ at levels slightly above those in our experiment elicited $100-163 \%$ increase in net $\mathrm{N}$ mineralization in boreal forest dominated by Pinus banksiana, a response that occurred immediately following the application of $\mathrm{NO}_{3}{ }^{-}$(Lamontagne and Schiff 2000). The time step for a response to occur, as well as the response itself, indicate that potentially different factors are controlling the influence of $\mathrm{N}$ deposition on net $\mathrm{N}$ mineralization. The stimulation of net $\mathrm{N}$ mineralization by long-term $\mathrm{NH}_{4}{ }^{+}$deposition in the northeastern U.S. might arise from higher leaf litter $\mathrm{N}$ contents which could stimulate decomposition and subsequently $\mathrm{N}$ mineralization; such a mechanisms does not appear to be in operation in our experiment. On the other hand, the rapid stimulation of net $\mathrm{N}$ mineralization in the boreal forest could not arise from a litter-initiated feedback, but must have arisen from some direct effect on microbial activity. The inconsistency of these responses, as well as the time step on which they occurred, suggests that microbial activity may be directly and indirectly altered by atmospheric $\mathrm{N}$ deposition. Understanding these mechanisms will be necessary if we are to reliably predict forest response to this component of global change.

Although the majority of our results suggest that atmospheric $\mathrm{NO}_{3}{ }^{-}$deposition had no effect on microbial $\mathrm{N}$ transformations in mineral soil, we did find a significant increase in annual net nitrification between our ambient and $\mathrm{NO}_{3}{ }^{-}$deposition treatment. Averaged across stands, annual net nitrification increased $27 \%$ under experimental $\mathrm{NO}_{3}{ }^{-}$ deposition. Although $\mathrm{NO}_{3}{ }^{-}$deposition did not significantly alter mean daily rates of net nitrification, they were generally more rapid in the $\mathrm{NO}_{3}{ }^{-}$ deposition treatment, and when summed over the entire year, produced a significantly higher mean annual rate. Our observation of increased net nitrification under experimental $\mathrm{NO}_{3}{ }^{-}$deposition is consistent with many other studies (Gunderson and others 1998; Lamontagne and Schiff 2000; Jefts and others 2004), but the mechanism responsible for these responses likely differs. In some studies, $\mathrm{NH}_{4}{ }^{+}$used to simulate atmospheric $\mathrm{N}$ deposition can increase the availability of substrate for nitrification; however, this was not the case in our study in which we added $\mathrm{NO}_{3}{ }^{-}$. We have previously demonstrated that ${ }^{15} \mathrm{NO}_{3}{ }^{-}$is initially assimilated by the microbial community, and it is then released as $\mathrm{NH}_{4}{ }^{+}$following the death of microbial cells where it can be taken up by roots or nitrifying bacteria (Zogg and others 2000). Rapid $\mathrm{NO}_{3}{ }^{-}$assimilation also occurred in our laboratory ${ }^{15} \mathrm{~N}$ tracer study, wherein $30 \%$ of ${ }^{15} \mathrm{NO}_{3}{ }^{-}$was incorporated into microbial biomass, DON and soil organic $\mathrm{N}$ over a 2-day period; in contrast, only $11-13 \%$ of ${ }^{15} \mathrm{NH}_{4}{ }^{+}$was recovered in these pools (Table 4). It is likely that microbial turnover of the additional $\mathrm{NO}_{3}{ }^{-}$and the subsequent production of $\mathrm{NH}_{4}{ }^{+}$stimulated net nitrification. In these northern hardwood forests, $\mathrm{NO}_{3}{ }^{-}$deposition has increased $\mathrm{NO}_{3}{ }^{-}$leaching by an order of magnitude; however, this response is not likely driven by the relatively small increase in net nitrification we observed under field conditions. Rather, much of the $\mathrm{NO}_{3}{ }^{-}$ deposited from our experimental treatment is directly leaching from this ecosystem, a response that is supported by the movement of ${ }^{15} \mathrm{NO}_{3}{ }^{-}$through soil (Zak and others 2004).

The results we present here clearly indicate that chronic $\mathrm{NO}_{3}{ }^{-}$deposition has not altered microbial respiration, biomass or $\mathrm{N}$ transformations in mineral soil and thus, cannot explain the sustained declines in soil respiration, as well as the greater export of DOC/DON from this ecosystem. The aforementioned responses may have originated in 
the forest floor, a portion of soil that we did not examine in this study. Forest floor is the initial entry point of anthropogenic $\mathrm{NO}_{3}{ }^{-}$into soil, and microbial activity in forest floor may be more responsive to $\mathrm{NO}_{3}{ }^{-}$deposition than in mineral soil (DeForest and others 2004a, b). Investigation into the microbial metabolism of leaf litter and changes in the function of mycorrhizae holds promise for understanding these ecosystem-level response to chronic $\mathrm{NO}_{3}{ }^{-}$deposition.

\section{ACKNOWLEDGEMENTS}

The National Science Foundation Division of Environmental Biology (DEB-9629842; DEB 0075397) provided support for the research reported in this paper. We thank Bob Vande Kopple for his assistance in the field, and we gratefully acknowledge access to our field sites by the Manistee National Forest and the Michigan Department of Natural Resources.

\section{REFERENCES}

Aber JD, Nadelhoffer KJ, Streudler P, Melillo J. 1989. Nitrogen saturation in northern forest ecosystems. BioScience 39:220-3.

Aber JD, Magill A, McNulty SG, Boone RD, Nadelhoffer KJ, Downs M, Hallett R. 1995. Forest biogeochemistry and primary production altered by nitrogen status. Water Air Soil Pollut 85:1665-70.

Aber JD, McDowell W, Nadelhoffer KJ, Magill A, Berntson G, Kamakea M, McNulty S, Currie W, Rustad L, Fernandez I. 1998. Nitrogen saturation in forest ecosystems: hypotheses revisited. BioScience 48:921-34.

Bowden RD, Rullo G, Stevens GR, Stuedler PA. 2000. Soil fluxes of carbon dioxide, nitrous oxide and methane at a productive temperate deciduous forest. J Environ Qual 29:268-76.

Bowden RD, Davidson E, Savage K, Arabia C, Steudler P. 2004. Chronic nitrogen additions reduce total soil respiration and microbial respiration in temperate forest soils at the Harvard Forest. For Ecol Manage (in press).

Bredemeier M, Blanck K, Xu YJ, Tietema A, Boxman WA, Emmett B, Moldan F, Gundersen P, Schleppi P, Wright RF. 1998. Input-output budgets at the NITREX sites. For Ecol Manage 101:57-64.

Brooks PD, Stark JM, McInteer BB, Preston T. 1989. A diffusion method to prepare soil $\mathrm{KCl}$ extracts for ${ }^{15} \mathrm{~N}$ analysis. Soil Sci Soc Am J 53:1707-11.

Burton AJ, Zogg GP, Pregitzer KS, Zak DR. 1996. Latitudinal variation in sugar maple fine-root respiration. Can J For Res 26:1761-8.

Burton AJ, Pregitzer KS, Ruess RW, Hendrick RL, Allen. MF. 2002. Root respiration in North American forests: effects of nitrogen concentration and temperature across biomes. Oecologia 131:559-68.

Burton AJ, Pregitzer KS, Crawford JN, Zogg GP, Zak DR. 2004. Simulated chronic $\mathrm{NO}_{3}{ }^{-}$deposition reduces soil respiration in northern hardwood forests. Glob Change Biol 10:1-12.
Carreiro MM, Sinsabaugh RL, Repert DA, Parkhurst DF. 2000. Microbial enzyme shifts explain litter decay responses to simulated nitrogen deposition. Ecology 81:2359-65.

Davidson EA, Hart SC, Firestone MK. 1992. Internal cycling of nitrate in soils of a mature coniferous forest. Ecology 73:114856.

DeForest JL, Zak DR, Pregitzer KS, Burton AJ. 2004a. Experimental $\mathrm{NO}_{3}{ }^{-}$additions alter microbial community function in northern hardwood forests. Soil Sci Soc Am J 68:132-8.

DeForest JL, Zak DR, Pregitzer KS, Burton AJ. 2004b. Nitrate deposition and the microbial degradation of cellulose and lignin in a northern hardwood forest. Soil Biol Biochem (in press).

Emmett BA, Boxman D, Bredemeier M, Gundersen P, Kjønaas OJ, Moldan F, Schleppi P, Tietema A, Wright RF. 1998. Predicting the effects of atmospheric nitrogen deposition on conifer stands: evidence from the NITREX ecosystem-scale experiments. Ecosystems 1:352-60.

Fenn ME, Poth MA, Aber JD, Baron JS, Bormann BT, Johnson DW, Lemly AD, McNulty SG, Ryan DF, Stottlemyer R. 1998. Nitrogen excess in North American ecosystems: predisposing factors, ecosystem responses, and management strategies. Ecol Appl 8:706-33.

Fog K. 1988. The effect of added nitrogen on the rate of decomposition of organic matter. Biol Rev 63:433-62.

Galloway JN. 1995. Acid deposition: perspectives in time and space. Water Air Soil Poll 85:15-24.

Gilliam FS, Yurish BM, Adams MB. 2001. Temporal and spatial variation of nitrogen transformations in nitrogen saturated soils of a central Appalachian hardwood forest. Can J For Res 31:1768-85.

Gundersen P, Emmet BA, Kjønass OJ, Koopmans CJ, Tietema A. 1998. Impact of nitrogen deposition on nitrogen cycling in forests: a synthesis of NITREX data. For Ecol Manage 101:37-55.

Hart SC, Stark JM, Davidson EA, Firestone MK. 1994. Nitrogen mineralization, immobilization, and nitrification. In: Weaver RW, Angle S, Bottomley P, Bezdicek D, Smith S, Tabatabai A, Wollum A, Eds. Methods of soil analysis part 2 microbiological and biochemical properties. Segoe, Wisconsin, USA: Soil Science Society of America, p 985-1018.

Haynes WE, Gower ST. 1995. Belowground carbon allocation in unfertilized and fertilized plantations in northern Wisconsin. Tree Physiol 15:317-25.

Holmes WE, Zak DR, Pregitzer KS, King JS. 2003. Nitrogen cycling beneath Populus tremuloides, Betula papyrifera and Acer saccharum growing under elevated $\mathrm{CO}_{2}$ and $\mathrm{O}_{3}$. Global Change Biol 9:1743-50.

Jefts S, Fernandez IJ, Rustad LE, Dail DB. 2004. Decadal responses in soil $\mathrm{N}$ dynamics at the Bear Brook Watershed in Maine, USA. For Ecol Manage 189:189-205.

Keyser P, Kirk T, Zeikus JG. 1978. Ligninolytic enzyme system of Phanerochaete chrysosporium: synthesized in the absence of lignin in response to nitrogen starvation. J Bacteriol 135: 790-7.

Lamontagne S, Schiff SL. 2000. Response of soil microorganisms to elevated nitrate input in an open Pinus banksiana-Cladina forest. For Ecol Manage 137:13-22.

MacDonald NW, Burton AJ, Jurgensen MF, McLaughlin JW, Mroz GD. 1993. Variation in forest soil properties along a Great-Lakes air-pollution gradient. Soil Sci Soc Am J 55: 1709-15. 
Magill AH, Aber JD, Hendricks JJ, Bowden RD, Melillo JM, Steudler PA. 1997. Biogeochemical response of forest ecosystems to simulated chronic nitrogen deposition. Ecol Appl 7:402-15.

Melillo JM, Aber JD, Muratore JF. 1982. Nitrogen and lignin control of hardwood leaf litter decomposition dynamics. Ecology 63:621-6.

Parsons WFJ, Kopper BJ, Lindroth RL. 2003. Altered growth and fine root chemistry of Betula papyrifera and Acer saccharum under elevated $\mathrm{CO}_{2}$. Can J For Res 33:842-6.

Pregitzer KS, Zak DR, Burton AJ, Ashby JA, MacDonald NW. 2003. Chronic nitrate additions dramatically increase the export of carbon and nitrogen from northern hardwood ecosystems. Biogeochem 68:179-97.

Ryan MG, Hubbard RM, Pongracic S, Raison RJ, McMurtrie RE. 1996. Foliage, fine-root, woody tissue and stand respiration in Pinus radiata in relation to nitrogen status. Tree Physiol 16:333-43.

Saiya-Cork KR, Sinsabaugh RL, Zak DR. 2002. The effects of long-term nitrogen deposition on extracellular enzyme activity in an Acer saccharum forest soil. Soil Biol Biochem 34:1309-15.

Treseder KK, Allen MF. 2000. Mycorrhizal fungi have a potential role in soil carbon storage under elevated $\mathrm{CO}_{2}$ and nitrogen deposition. New Phytol 147:189-200.
Vitousek PM, Aber JD, Howarth RW, Likens GE, Matson PA, Schindler DW, Schlesinger WH, Tilman DG. 1997. Human alteration of the global nitrogen cycle: sources and consequences. Ecol Appl 7:737-50.

Vogt KA, Vogt DJ, Gower ST, Grier CC. 1990. Carbon and nitrogen interactions for forest ecosystems. In: Person $\mathrm{H}$. Ed. Aboveand gelowbround interactions in forest trees in acidified soils. Belgium: Commission of the European Communities. p 203-35.

Wallander H. 1995. A new hypothesis to explain allocation of dry matter between mycorrhizal fungi and pine seedlings in relation to nutrient supply. Plant Soil 169:243-8.

Wallenda T, Kottke I. 1998. Nitrogen deposition and ectomycorrhizas. New Phytol 139:169-87.

Zak DR, Pregitzer KS. 1990. Spatial and temporal variability of nitrogen cycling in northern Lower Michigan. For Sci 36:367-80.

Zak DR, Pregitzer KS, Holmes WE, Burton AJ, Zogg GP. 2004. Anthropogenic $\mathrm{N}$ deposition and the fate of ${ }^{15} \mathrm{NO}_{3}{ }^{-}$in a northern hardwood ecosystem. Biogeochem 69:143-57.

Zogg GP, Zak DR, Pregitzer KS, Burton AJ. 2000. Microbial immobilization and the retention of anthropogenic nitrate in northern hardwood forests. Ecology 81:185866. 